\title{
Strategic thinking and accounting: potentials and pitfalls from a managerial perspective
}

\author{
Pasi Aaltola ${ }^{1}$ D \\ Published online: 27 June 2019 \\ (C) The Author(s) 2019
}

\begin{abstract}
This study explores the strategic thinking of managers from an accounting perspective. By building on interview data from managers working with strategic roles in various organizations, an understanding is offered of the experienced potentials and pitfalls of accounting in strategic thinking. The results are elaborated into a framework presenting the dual nature of accounting in strategic contexts. This study suggests that the benefits and pitfalls of accounting for strategic thinking constitute a paradoxical duality, which cannot be fully solved, but must be addressed by practising managers. The observed role of accounting in managers' strategic thinking also offers implications for management control in organizations.
\end{abstract}

Keywords Managerial work $\cdot$ Accounting $\cdot$ Strategic thinking $\cdot$ Management accounting $\cdot$ Management control

\section{Introduction}

Accounting is used to produce reports representing the past and the current situation, but what about the strategic foresight and visioning aspect of managerial work? This article aims to extend our understanding of the role of accounting in practicing managers' strategic thinking as they generate ideas for business model development, strategize in order to create success for the future and quantify their strategic plans and intentions in terms of desired financial outcomes. In addition to exploring the potential benefits of using accounting in a strategic thinking context, especially the limitations and pitfalls of such an approach are theorized in this study.

Previous studies have explored strategic thinking in managerial work (e.g. Zabriskie and Huellmantel 1991; Heracleous 1998; Liedtka 1998; Bonn 2001, 2005; Tavakoli and Lawton 2005; Nuntamanop et al. 2013). This literature highlights

Pasi Aaltola

pasi.aaltola@jyu.fi

1 Jyväskylä University School of Business and Economics, University of Jyväskylä, P.O. Box 35, 40014 Jyväskylä, Finland 
explicit business impacts by suggesting that strategic thinking should be hypothesis driven (Liedtka 1998) and emphasizes a rational approach (Bonn 2005) and analytical thinking ability (Nuntamanop et al. 2013) as part of strategic thinking. Yet this literature does not outline any specific ways that accounting might play a role in strategic thinking of managers. Even though accounting practices have been suggested to be central to organizations and their management (Brouthers and Roozen 1999; Miller and Power 2013), the connection of strategic thinking to accounting seems to be a rather unexplored area in research.

Literature on accounting and control has pointed to the importance of organizations' strategizing and innovation activities (Davila et al. 2009; Simons 1995, 2000). The traditional view of management control systems in which they are considered to merely implement strategies (Anthony 1965), has been questioned. The management control literature suggests that the formulation and implementation of strategies are interdependent and that the role of the people at different levels of the company is to work actively to maintain the viability of their organization (Otley 1994; Kaplan and Norton 2004). There is also an extensive tradition in contingency-based research of examining management control emphasizing structures rather than actors (Chapman 1997; Chenhall 2003). However, the existing literature on accounting and control has been criticized for concentrating too much on organization-level analysis (Davila et al. 2009; Tervala et al. 2017; Chenhall and Moers 2015), which therefore creates the need to understand individual actors. There have been a number of calls to promote a managerial perspective in accounting research and aligning accounting research more with the actual practice of managerial work (e.g. Chua 2007; Jönsson 1998; Gerdin et al. 2014; Hall 2010). However, in spite of some recently published papers that focus on practicing managers (Goretzki 2013; Tayles et al. 2007; Jordan and Messner 2012; Burkert et al. 2011; Pfister et al. 2017), there seems to be little, if any, research focusing on the essence of accounting from the personal standpoint of individual managers. This study is inspired by these observations, therefore the individual manager, instead of the organization, is chosen as the unit of analysis in an attempt to understand accounting in the context of strategic thinking.

There are many published studies describing the dual nature of accounting, with its positive and negative effects (e.g. Denis et al. 2006; Nutt 1998; Frishammar 2003; Kutschera and Ryan 2009; Cooper et al. 2001; Whittle and Mueller 2010; Mastilak et al. 2012). The use of management control systems has also been characterized as a duality of enabling and coercive controls (Adler and Borys 1996; Ahrens and Chapman 2004). Furthermore, it has been found that the perception of coercive and enabling form of control can change over time (Jordan and Messner 2012) and coexist simultaneously (Adler 2012). This study approaches the dual nature of accounting recognized in the previous literature by adopting a practice-oriented approach (Lövstål and Jontoft 2017), examining the tensions that managers confront specifically in their strategic thinking. The research question of this study is as follows: What are the ways in which experienced managers find accounting useful in strategic thinking and what are the disadvantages they have experienced? With this aim, the present study responds to calls to study subjective mechanisms and informal systems of control (Reimer et al. 2016; Tervala et al. 2017; Martyn et al. 2016) and aims to extend the understanding of contemporary research by providing explanations for 
why accounting is often seen to be problematic and, therefore, absent (e.g. Choudhury 1988; Taipaleenmäki 2014) in strategic contexts.

A qualitative interpretative research approach is adopted to expand our view by interviewing 23 experienced managers from various organizations and exploring the ways in which accounting plays a role in their strategic thinking. The results are formed through qualitative content analysis (Hsieh and Shannon 2005) building on Bonn's (2005) definition of strategic thinking, seeing it as a way of solving strategic problems that combines a rational and convergent approach with creative and divergent thought processes. The results of this study show that accounting is found to be useful, but simultaneously also having its disadvantages in a variety of strategic thinking contexts. Organizational accounting and management control practices were found to set frames for the individual's strategic thinking, discouraging managers from quantifying their strategic intentions and using accounting in their strategic endeavours. The results build an understanding of accounting's role in strategic thinking, extending it from the components of making a decision into the initial framing of the strategic setting and setting the choices made into motion. The results are elaborated into a framework presenting the dual nature of accounting suggesting that the benefits and pitfalls of accounting for strategic thinking constitute a paradoxical duality, which cannot be fully solved, but must be addressed by practising managers. The theoretical contribution of this study includes the observed dual role of accounting in managers' strategic thinking and its implications for management control in organizations. These findings help us to understand contradictory yet interrelated paradoxical elements (Smith and Lewis 2011) of accounting and managers' need to address these competing demands simultaneously.

The rest of this article is organized as follows. Section 2 contains the literature review. Section 3 describes the methodological setting and interview data collection. Section 4 lays out the study's main results. Section 5 makes conclusions and offers implications of this article, addresses limitations of the research and outlines avenues for further research.

\section{Literature review}

\subsection{Strategic thinking}

Strategic thinking has been defined in many ways. Näsi (1991) characterizes strategic thinking broadly, covering all attributes under the term that can be labelled strategic: "Strategic thinking extends both to the formulation and execution of strategies by business leaders and to the strategic performance of the total enterprise. It includes strategic analysis, strategic planning, organization and control and even strategic leadership" (Näsi 1991: 29). Mintzberg (1994) separated strategic thinking from strategic planning. He stated that strategic planning is an analytical process that programmes and formalizes already existing strategies, whereas strategic thinking involves intuition and creativity. This view is supported by Heracleous (1998) and Graetz (2002) who have also separated strategic thinking and strategic planning from one another, but stated that they are both 
important for strategic management. Bonn (2001) lists three elements of strategic thinking on an individual level: (1) holistic understanding about the organization and its environment, (2) creativity and (3) a vision for the future of the organization. Liedtka (1998) has defined strategic thinking as a particular way of thinking that consists of five elements: (1) systems perspective, (2) intent focused, (3) thinking in time, (4) hypothesis driven, and (5) intelligent opportunism. Kaufman et al. (2003) characterize strategic thinking from a managerial perspective as "practical dreaming", that is, as creating an ideal future by defining and achieving results that add value.

Although there is no general agreement in the literature on how to specifically define strategic thinking, the need for such thinking is clear (Steptoe-Warren et al. 2011) and calls for further research supporting organizations' attempts to innovate their business models have been made (Laamanen 2017). Thinking strategically-finding alternative strategies and business models to create customer value-has been stated as an important part of every manager's job (Abraham 2005) and, furthermore, it has been suggested that the more an organization has people thinking strategically, the more readily it can respond to changes in the business environment (Tavakoli and Lawton 2005). There is existing research about the roles related to the work and performance of strategy practitioners in organizations (Nordqvist and Melin 2008), factors that influence strategic thinking at the organizational level (Moon 2013) and leadership practices that can encourage it in organizations (Goldman 2012). How strategic thinking develops in individuals has been explored (Goldman 2005; Dragoni et al. 2011), as has how it can be learned (Casey and Goldman 2010) and how it can be fostered through training (Benito-Ostolaza and Sanchis-Llopis 2014).

Three elements, which build on Bonn's (2005) definition and pull together the widely shared perspectives in the literature, are used to define the characteristics of strategic thinking in this study. First, a holistic understanding of the organizational context (Bonn 2001, 2005) is emphasized to highlight a systems perspective, a mental model of 'how the world works' (Liedtka 1998). Second, a visionary and proactive perspective (Bonn 2001, 2005) is included, suggesting that strategic thinking is fundamentally about developing new ideas (Stacey 1992). Acknowledging that managers do "think about strategies" in the strategy execution phase as well, strategic thinking is approached in this study from the perspective of strategy development, as a future-oriented managerial activity, as seeking innovation and visions regarding the directions that the organization should pursue (Mintzberg 1994). A strategy execution perspective is addressed only in the sense of arguing for generated strategic initiatives in the organization, not in focusing on the actual implementation of the developed strategic initiatives. Third, an innovative and creative, business-focused approach to adding customer value (Bonn 2001, 2005) is included. The market orientation is also highlighted by Moon (2013) and Abraham (2005), who describe strategic thinking as finding alternative strategies and business models to create customer value. The use of this three-fold definition of strategic thinking in this study's data selection is outlined in more detail in Sect. 3. 


\subsection{Strategic thinking and management accounting}

The existing literature has recognized the significance of aligning accounting research more with the actual practice of managerial work (e.g. Chua 2007; Jönsson 1998; Gerdin et al. 2014; Hall 2010) and to the developments within the strategy field (Nyamori et al. 2001). Research on strategic management accounting (SMA) has aimed to strengthen the connection between accounting and strategic management (Roslender and Hart 2003). SMA can also be seen to reflect the corporate-level need for accounting information that could be more useful in strategic contexts (Cinquini and Tenucci 2010). Accounting and calculative practices have even been suggested to act as engines in seeing new business opportunities (Revellino and Mouritsen 2015). The literature on management control has approached the initial phase of strategy development from various perspectives. The traditional view where management control was seen as unsuitable for innovation and strategic development has been challenged (Chenhall and Moers 2015). Whereas management accounting practices such as the balanced scorecard (Kaplan and Norton 1996) are primarily focused on managing performance along an already chosen strategic path, Simon's levers of control framework (Simons 1995, 2000) was pivotal in emphasizing the interactive use of controls aiming at exploring the strategic uncertainties. However, despite the previous work, the existing research has been criticized for mainly focusing on exploring control issues within formal company practices and structures on an organizational level (Tervala et al. 2017; Chenhall and Moers 2015). Much of the prior research has concentrated on which accounting techniques are used and how and in what circumstances in organizations (e.g. Bisbe and Malagueno 2009; Chapman 1997; Chenhall 2003; Davila et al. 2009; Tervala et al. 2017; Chenhall and Moers 2015). To date, there has been very little attention on the use of accounting in strategic thinking from an individual manager's standpoint.

Some research does exist, however, that emphasizes individual actors' perspectives on the issue. Accounting's role in the management process has been explored from a cognitive point of view (Busch 1997), a sensemaking perspective (Gerdin et al. 2014; Puhakka 2017) and in how strategic initiatives are argued for (Dutton et al. 2001; Whittle and Mueller 2010). One interesting strand of accounting research has also been carried out in the area of innovation and new product development (e.g. Duhamel et al. 2014; Taipaleenmäki 2014; Jorgensen and Messner 2010; Davila 2000; Feeney and Pierce 2016; Nixon 1998). On the other hand, these settings are often manufacturing oriented and rather technical and structural by nature. Strauß and Zecher (2013) suggest that further research is needed since management control system approaches were developed at a time when most organizations were manufacturing products. This represents fairly precise and traditional contexts for accounting and decision-making. Even in these cases, management accounting has been found to be absent for various reasons, or when present, to provide the intended value to a limited extent. New product development and accounting studies typically build understanding about the adoption and use of different management control systems on a company level (Bisbe and Otley 2004; Bisbe and Malagueno 2009; Ditillo 2012; Mouritsen et al. 2009) instead of focusing, for example, on how decision-makers evaluate alternatives and use analytics in their strategic thinking. 
Significant analysis and discussion on the variety of reasons for using formal analysis in strategic decision-making has been presented by Langley (1989). She found that analysis could be initiated for information purposes (aimed at gaining information for decision-making), persuasion and communication (in order to communicate ideas to others), direction and control (to ensure action on the part of subordinates), and symbolism (to convey a symbolic message about the strategic issue and intentions and actions regarding it). Mueller et al. (2007) have applied Langley's framework in their study of organizational performance. They decomposed the concept of rationality according to Langley's (1989) framework and related these subunits to firm performance, emphasizing the importance of the definition of rationality when examining its effects on organizational performance. Kaikkonen (1994) presents another attempt to combine various perspectives on the uses of accounting in strategic contexts into a framework. He proposed an original viewpoint by examining strategic thinking from an accounting perspective and as a conceptualization that occurs in an individual strategist's consciousness. He presents four areas where accounting could play a role in strategic thinking. First, accounting contributes to the construction of the strategist's own world-picture when an individual applies concepts of accounting in their interpretations of the enterprise. Second, accounting has a role in strategic thinking through possible means of analysis and analytical practice. Third, accounting may fulfil the need for conviction in alleviating the fundamental sense of uncertainty regarding the future. Fourth, accounting functions as means of communication, because strategic issues are typically objects of debate and change that are concerned with shared meanings.

Whereas Langley's (1989) framework is multidimensional in its presentation of decision process rationality, it is also limited in its chosen focus on examining written, documented analytical studies in companies around strategic decision-making and scoring them according to their length and analytical sophistication. Furthermore, Langley's model extends to the strategy implementation phase, whereas Kaikkonen's framework focuses specifically on strategic thinking, the initial phase of future-oriented managerial activity seeking innovation. For the reasons described before and taking into account the defined focus of this paper (the perspective of individual managers), Kaikkonen's conceptual and linguistic work is more appropriate for structuring the uses of accounting in strategic thinking in this study. The four areas of Kaikkonen's (1994) theoretical and linguistic work can be used to draw together various perspectives presented in the existing literature. Accounting's role in contributing to the strategist's world-picture resonates with research on the strategic alignment of development with corporate strategy (Akroyd et al. 2016; Slagmulder 1997) as well as the sensemaking perspective, where accounting is seen as forming organizational life and actors' interpretations of it (Gerdin et al. 2014; Puhakka 2017; Miller and Power 2013; Haukedal and Gronhaug 1994; Tillman and Goddard 2008). The second area, analysis, is consistent with the literature exploring accounting's role in evaluating strategic alternatives and using analytics in decisionmaking (e.g. Nutt 1998; Frishammar 2003). While it should be acknowledged that intuition plays a significant part in decision-making (Kutschera and Ryan 2009), it is essential to recognize that intuition alone does not constitute strategic thinking (Sloan 2014). The need for conviction echoes with perspectives addressing strategy 
as a creative interpretation of the future, where accounting and numbers bring plausibility and legitimacy to the setting (e.g. Goretzki 2013; Sajasalo et al. 2016; Weick 1995). In the same vein, Denis et al. (2006) suggest that the power of numbers is to fill the strategic void created by pluralism. The communication aspect is in line the literature on how strategic ideas are argued for and influenced (Dutton et al. 2001; Whittle and Mueller 2010; Lechner and Floyd 2011). The role of communication and interaction around strategic ideas also resembles Simon's (1995) idea of interactive controls and how management accounting and control systems could be regarded as communication platforms on strategic issues (Heidmann et al. 2008; Pärl 2014). The use of documented quantifications have been described as technologies of distance, well suited for communication that goes beyond the boundaries of locality (Porter 1995), expediting long-distance control (Robson 1992).

In addition to the previously described benefits of using accounting in strategic thinking, existing research has also pointed to the absence and various disadvantages of accounting in strategic contexts. Critical views have been presented about the use of accounting and calculative practices in future-oriented strategic planning (Cooper et al. 2001; Whittle and Mueller 2010) and the low involvement of management accounting in strategic decision-making (Brandau and Hoffjan 2010). Justified concerns have also been raised regarding the low-level adoption of SMA (LangfieldSmith 2008) and the contradiction between the decline of strategic management accounting (SMA) and the growth in the number of concepts and frameworks in the strategic management domain in general (Nixon and Burns 2012). Denis et al. (2006) suggest that the role and power of numbers might have unexpected consequences, detaching agency and the responsibility of actors and limiting their opportunities to make reasonable adjustments in their actions when needed. Furthermore, they conclude that numbers systems are always reductionist and rarely sufficient to deal with the complexity of strategy making. Mastilak et al. (2012) found that enhancing the BSC system with strategy maps might cause evaluators to hold managers more responsible for achieving success despite uncontrollable factors, leading to unintended consequences. In addition to drawing attention to these observed disadvantages of using accounting, previous research has also found accounting to be totally or partially absent in strategic contexts (Nixon and Burns 2012; LangfieldSmith 2008; Brandau and Hoffjan 2010; Taipaleenmäki 2014).

While previously described streams of literature offer a range of evidence for the benefits of accounting in strategic thinking and suggest possible reasons for accounting's absence, the results remain diverse. Taken together, the studies presented thus far provide evidence that accounting is seen to have both positive and negative effects in strategic contexts. For example, overuse of formal analysis, that is, the systematic study of issues, can lead to paralysis by analysis (Kast and Rosenzweig 1970; Langley 1995), but unaided intuition-driven human judgment is also frequently found to be flawed (Kahneman 2011). Managerial rationality has been suggested to be context specific (Haukedal and Gronhaug 1994). Frishammar (2003) found that the combination of using hard numerical and soft subjective information is contingent on the specific decision at hand. In a similar vein, Lechner and Floyd (2011) found that if strategic initiatives were more exploratory-meaning innovative undertakings with goals and methods that are inconsistent with an organization's 
current competencies - they were less likely to be successful in the resource allocation process. The existing literature, on the whole, suggests that accounting in a strategic thinking context is not a neutral thing, but could been seen as a duality, one with the potential to provide both advantages and disadvantages to the process.

Some recent studies have specifically addressed the dual nature of management accounting and control. A number of researchers have examined the actors' perceptions of management control as a duality of enabling control that allows actors to deal with the contingencies that arise in their work, and coercive controls enforcing compliance (Adler and Borys 1996; Ahrens and Chapman 2004). This stream of literature has found that the perception of coercive and enabling forms of control can change over time (Jordan and Messner 2012) and coexist simultaneously (Adler 2012). Recently, some scholars have addressed this problematic as a source of tension. Lövstål and Jontoft (2017) have suggested that the phenomena of management control and innovation can create tensions by presenting competing demands. Tensions related to accounting and control (arising from, e.g., seeing intuition and rationality as alternative decision-making strategies), have been suggested to be managed by paradoxical thinking, leveraging both approaches to the issue (Calabretta et al. 2017). This study responds to a suggestion to study the multidimensional and dynamic relationship between strategy and accounting (Chua 2007). Previous studies have recognized but not sufficiently addressed the duality of accounting in the context of strategy from the perspective of individual managers. This study responds to a call for further research by adopting a practice-oriented approach suggested by Lövstål and Jontoft (2017) and examines the tensions that individual managers confront in their strategic thinking.

\section{Methodology and research design}

This qualitative explorative research utilizes content analysis, which classifies data into fewer content categories, thereby providing a meaningful interpretation of the topic (Weber 1990; Patton 2002). Qualitative content analysis (QCA) is systematic (Schreier 2014), but it also makes it possible to leverage conceptual and analytical flexibility (Duriau et al. 2007). QCA can be applied with three distinct approaches: summative, directed and conventional (Hsieh and Shannon 2005). This study utilizes directed content analysis based on existing theory in defining its key concepts from the interview data on managers' use of accounting in the context of strategic thinking. Next, conventional content analysis with codes more inductively derived from the data is used to describe managers' views on the disadvantages of using accounting in strategic thinking.

The data were collected through a university executive MBA programme. The programme attracts executive students with substantial professional experience and it is internationally accredited by the Association of MBAs. The interviewees were chosen from among the EMBAs who graduated between March 2011 and March 2014. In order to gain as rich data set as possible, the interviewees (23) were selected from among all graduates (108) who addressed strategic thinking in their EMBA final thesis. The total of 108 theses included many kinds of projects 
on various managerial topics. In order to identify those reports that would provide data for examining the strategic thinking of managers, a refined lens derived from the theory (see Sect. 2.1) was used. All 108 EMBA theses were read and the ones that met all the following three criteria qualified for the group of theses reflecting strategic thinking.

1. Holistic understanding of the organizational context

When studying strategic thinking from an accounting and managerial perspective, the inclusion of holistic understanding of the organizational context is well grounded. Without linking strategizing to the future of a specific organization, the managerial responsibilities, accountability and the use of resources would be excluded from the picture. Strategic thinking and accounting can only be adequately studied in the context of a firm.

2. A visionary and proactive perspective

This future orientation excluded reports that reflected only on past development and that would possibly include accounting information produced after the original chain of events.

3. Innovative business-focused approach aiming to add customer value was the third criterion, and it aimed to include only those creative reports which had a clear connection to the future business models of the organization. Internal change plans or projects were excluded as well as theses focusing only on leadership and management issues.

The three criteria formed a strict filter for choosing the respondents for the interviews. The number of theses that met all three criteria was 26 of 108 . The length of the 26 reports was 1754 pages in total and 67 pages on average. For an overview of the nature of the projects, see "Appendix A", which lists the titles of all 26 theses. All 26 managers were asked to be interviewed and all stated their willingness to participate. One respondent, however, was unavailable to attend an interview for practical reasons during the period of data collection. Two respondents were omitted from the interviews by the researcher since their job descriptions had changed and did not currently include managerial responsibilities with a strategic emphasis. Ultimately, 23 managers were interviewed during March-June 2015. The interviews were conducted in person, recorded and transcribed. Anonymity was guaranteed to the respondents before they participated in the interviews. The interviews lasted, on average, for $1 \mathrm{~h}$ and 8 min (shortest: $41 \mathrm{~min}$; longest: $1 \mathrm{~h}$ and $36 \mathrm{~min}$ ) and in total $27 \mathrm{~h}$ and $47 \mathrm{~min}$. Fifteen interviewees currently held a position that included the title of director (e.g. managing director, development director), and seven held other managerial positions. In addition to the EMBA which they all had more recently completed, 9 interviewees held a master's level degree, 13 held a bachelor's or vocational degree and 1 had a doctoral degree. "Appendix C" presents descriptive details of the interviewees.

Rather open-ended questions were chosen to guide the course of the interviews. The interview themes were structured based on the literature review and categorized by reflecting the key themes of this study: managerial work perspective, 
strategic thinking, strategic thinking and accounting (see the agenda of the interviews in "Appendix B"). The aim was to encourage respondents to share practices they use and experiences they have had exceeding the officially set procedures in their organizations. In addition, the order of the topics discussed in interviews supported the aim of gaining their personal managerial view of the issue. The interviews started with more general questions and then progressed in stages to strategic issues. The questions covered the field of strategic thinking and accounting comprehensively, from more general questions about the respondents' work and their relationship with accounting to a discussion of how strategic initiatives are sold and gain legitimacy in an organization. Information about their EMBA projects was covered in the end as one example of strategy-related initiatives, so that experiences and characteristics from that specific case would not direct the whole course of the interview. The topic was approached without using any limiting, though well-established, concepts such as financial accounting or management accounting as a starting point. However, even the data collection was not, in principle, limited to management accounting, the data mainly focused on the phenomena found in the management accounting field.

In qualitative content analysis, the coding frame is at the heart of the method. In this study, the approach to the interview data was split into two phases that formed the main categories of its content analysis, with the code development and application being performed consecutively and separately. All the interview material was double-coded and the analysis was implemented according to the qualitative content analysis requirements for unidimensionality and mutual exclusiveness for coding frames (Schreier 2014). Unidimensionality of the interview data was achieved by approaching the research question with two dimensions featuring distinct subcategories, capturing only one aspect of the data at a time. The first main category was managers' use of accounting in strategic thinking. The coding categories were created in a concept-driven way from existing theory, with Kaikkonen's (1994) theoretical framework being adopted as a basis for organizing the data. The first round of analysis was carried out in order to determine whether additional coding subcategories were needed. The exhaustiveness of the coding frame was regarded as valid to the extent that the categories adequately represented the concepts in the research question, and it was not necessary to adapt the coding frame to fit the material. All subcategories were used and easy to apply with no significant overlap. In the main analysis it was found that the coding frame based on Kaikkonen's framework provided a valid description of the material. After analysing the uses of accounting, the second main category in the content analysis of the interviews was established as the reasons for not using accounting in the context of strategic thinking. The material was first coded in order to translate all meanings in the material that were relevant to the research into the categories of a coding frame. The subcategories for this were created in a data-driven way using subsumption (Schreier 2012), a strategy for generating data-driven subcategories in an already existing main category. The coding frame was created by adding data-driven subcategories and subsuming those new subcategories into already existing subcategories if they failed to add anything new. All meanings in the material that were of interest to the research question 
were translated into the categories of a coding frame and this process of coding frame development was carried out with all of the data. After that the frame was revised and overlapping subcategories collapsed. This data-driven coding frame was saturated by definition, meaning that each subcategory was used at least once (in practice 6-17 times) during the analysis.

\section{Interviews on managers' strategic thinking and accounting}

The first set of analyses examined managers' uses of accounting. A variety of perspectives were expressed in describing the benefits of accounting in the context of strategic thinking. The following presents the main findings of the interviews, drawing on Kaikkonen's (1994) four-dimensional classification.

\subsection{Construction of strategist's own world-picture}

A recurrent theme in the interviews was a sense amongst interviewees that accounting contributed to the construction of strategic understanding. Sixteen interviewees highlighted the role of accounting concepts in interpreting their strategic setting, thus emphasizing the construction of the strategist's own worldpicture. One manager, for example, talked about the issue in the following way:

Numbers help you to understand things, about where are we coming from, where we are and where we are going. They concretize in a certain way, they set certain kinds of frames about what is going on. You can't do strategic planning totally without numbers.

Another respondent described the connection between accounting information and forming the strategic big picture of the business model:

If you examine some single things, they might turn out to look unprofitable. But you have to be able to see their role in the bigger strategic picture. Without keeping some components in our offering portfolio, we might be out of the game in the long run. You just need to understand the bigger picture.

Constructing the world-picture was also addressed through the strategic resources of the company. Many respondents described accounting's role as essential in understanding the strategic resources of the company (e.g. based on its balance sheet) and therefore its capacity to expand its business and make strategic investments. Accounting was considered to play a role in forming this view and understanding the business environment. For a strategist, constructing an understanding of the dynamics of building a successful organization and one's role in that setting is essential. Taken together, these results suggest that manager's strategic thinking is context specific and accounting was found to play a role in that ongoing process of constructing the strategist's world-picture. 


\subsection{Analytical thinking}

Accounting was found to have a role in analytical thinking contributing to a manager's analysis through the use of numbers and quantification. One director explained accounting's role in the following way:

I think that I also have to analyse in terms of numbers what has happened and where we are going. A leader who does not analyse the figures and does not understand what they are, takes a risk. In that case the ship would sail without a steering wheel and a rudder.

This view was echoed by another informant who described the use of analysis in his decision-making:

The more you keep digging in that information and analysing it, the more useful it is. It is so clarifying to see the idea on paper with real figures that you always try to do it. You realize that your gut feeling might be wrong, so no matter how long you have been doing something, you can quite easily get lost.

However, the role of accounting in analytical thinking was the least emphasized in the interview data, mentioned by only six interviewees. Even this result is somewhat counterintuitive considering the variety of calculative practices and analytical tools of accounting; accounting was found to play a role nevertheless. Typically in these cases the strategic setting of the respondents involved issues in manufacturing and product portfolios with significant volume and complex cost structures. In areas with less precise premises for analytical calculations (e.g. business model innovation and new strategic initiatives) it was found to be emphasized less or to appear absent.

\subsection{Need for conviction}

The third area, the need for conviction, formed another distinctive theme in managers' use of accounting in strategic thinking. It often referred to employing accounting to alleviate a sense of uncertainty and to convince oneself regarding the feasibility of the strategic plans at hand. Comment from an interviewee highlights the issue as follows:

If there is a new thing [business idea], I always try to asses it in terms of money myself. You also have to see what kind of business potential you are talking about, so that you don't get too excited about too little things. That can easily happen when you get truly inspired about something. You have to understand it [a strategic idea or a business plan] yourself before you start talking about it to others.

This indicates that managers do utilize accounting to test their assumptions and to satisfy their need for conviction. Furthermore, accounting has a role when managers devote themselves to the chosen strategic choices. This was echoed by another informant, who stated the following: 
Well you try to pressure test it (by analysing the idea financially) after the idea has been invented. There it is weighed whether the idea is viable or not. And at the same time you create arguments for promoting the idea.

Using accounting to bring plausibility into the ambiguous setting of strategic thinking was prominent in the interview data. The previous quote emphasized the need for conviction in a way that leads to the last theme: the use of accounting in communication.

\subsection{Communication}

The fourth theme for accounting in strategic thinking was communication. Often the stories addressing this theme were about promoting the strategic ideas and communicating their value potential for decision-makers. The following quote illustrates the point:

I would not get anything accepted by merely saying that this supports our strategy. I have to be able to demonstrate that it (a strategic development project) will be a good investment. Even strategic projects are such that at some point they add value or save costs that is more than the amount invested in development.

In a similar vein, another interviewee stated that:

I don't know whether it is good or bad, but at least in our organization due to our financial situation, you have to be able to demonstrate a really strong business case before we go ahead with anything. For example, if you are thinking about expanding the business and proposing developmental investments for that, then you have to have a real solid examination with financial facts before you can get it approved.

In addition to the previously illustrated widespread view of using accounting in order to justify an action and receive official decisions for moving forward with strategic initiatives, interviewees highlighted a further form of communication. Accounting was used in attempts to influence the meaning construction of actors in the organization other than the official decision-makers. Based on his/her strategic view and standpoint, the strategist is understandably motivated to establish new patterns of actions in an organization, and accounting has a potential role in this communicational process. One director described the issue as follows:

If you can dress it in the form of numbers, it will have some kind of more objective basis. Strategy is a very abstract thing so if you can make it more understandable, then it has a lot of effect in terms of implementation; people can see what you are after.

Together these results provide important insights into the use of accounting in managers' strategic thinking. The four themes describing the experienced benefits of accounting were prominent in the data. However, the results echo the previous literature by highlighting the absence of accounting (Nixon and Burns 2012; 
Langfield-Smith 2008; Brandau and Hoffjan 2010; Taipaleenmäki 2014) and showing that the one conventional and often most explicit part of using accounting, analysis, was emphasized by only a few respondents. The discrepancy between the potential use of accounting and practice remains. The first analysis of the data outlined the uses of accounting where it is found to be potentially useful for the manager. On the contrary, this perspective did not bring forth any of the aspects that might discourage managers from quantifying their strategic intentions and using accounting in their strategic endeavours. To conceptualize this contrasting side of the issue, another kind of analysis of the interview data was needed. This second analysis was carried out inductively in a data-driven way without utilizing any pre-existing theoretical framework. The second main category identified in this analysis outlined the reasons for not using accounting in the context of strategic thinking. The second analysis revealed the following four factors describing the disadvantages of using accounting in strategic contexts.

\subsection{Hindering a strategic mindset}

The first disadvantage was "hindering a strategic mindset", and it describes the ways in which accounting was seen not to act in favour of supporting strategic thinking, but the opposite. One director stated the following:

If you tell a CFO about a new idea, the first question is how much will this cost and how much will it generate revenue. Well, I see that it can easily kill innovations if you include the numbers in the process too early.

In a similar vein, another respondent described how the use of accounting might seem solid in itself, but that in time it can also reduce innovation efforts in an organization.

If you have an idea and already before the decision is made whether we shall take it forward and test it, if there are very strict frames and you must calculate the internal rate of returns and everything for it, my view is that it raises the threshold for brainstorming too high.

In summary, the theme of hindering strategic mindset was often related to organizational practices that emphasized accounting in a way that led to the hamstringing of ideas and efforts regarding new strategic suggestions. This highlighted the other side of the matter, in contrast to the identified use of accounting in constructing the strategist's world-picture.

\subsection{Inability to quantify future}

The second disadvantage was related to analytical thinking, and more precisely to the challenges of using calculative practices in future-related strategic thinking. These limitations of using accounting were widespread in the data and offered critical views about the usefulness of accounting when looking ahead. This theme of "inability to quantify future" is aptly described by the following interviewees. 
When looking at the future, I don't really see any role for accounting information in that process. For example, we drew up our strategy in such a way that we set no numeric goals or key figures in advance, as we have traditionally done. We thought about productizations we have to make, account management we have refigure etc. and that produces certain numbers but the key goal is that we have to be better than today. The world nowadays is so complex that you can't take such a numerical standpoint that you could say that these choices will lead us to these kinds of financial outcomes.

Another informant stated the following:

There aren't any absolute truths out there [regarding business development]. You have to know the customers, the field of industry, technology, legislation, etc., but there are always surprises which can be become noticeable through weak signals or through someone's opinions. In the planning phase if we think about doing revenue calculations, those are rather uncertain predictions before we have any real offers out sent to the customers and any closed deals. Before that, it is only our vague perception of the matter, not facts.

A common view amongst the interviewees was that accounting is limited in its capability to analyse planned strategic initiatives in order to quantify their potential outcomes in advance. This inability to quantify the future in strategic thinking was aptly described by the following respondent, who refers to the potential use of accounting merely in the later implementation stages of the process:

It is extremely hard to set exact goals in advance. At some point along the way it starts to unfold in a way that, okay, there is a change, but that venture then it is quite far at the point when you start looking at it through real numbers.

\subsection{Cautious short-sightedness}

As the third disadvantage, respondents raised concerns that the use of accounting can lead to "cautious short-sightedness". In many ways, it was found to be challenging to alleviate uncertainty through quantifying future-related issues. By using accounting one can be convinced regarding issues that are more easily quantifiable, typically short-term issues with a tactical nature. In a strategic setting, looking for conviction through accounting and numbers can lead to a lack of courage at the expense of learning and going forward. One interviewee explained:

Sometimes accounting in a strategic context limits daring and risk-taking. Sometimes you need to be able to be sure that those problems will be solved along the way. If you calculate too strongly through numbers it might be that you base your decisions too much on numbers and many steps are left untaken and many things not achieved.

Cautious short-sightedness was seen to have far-reaching consequences also on an organizational level, when it leads to refraining from strategic development actions. Many respondents described situations in which short-sighted 
performance reporting and measurement neglected strategic development. One interviewee described the issue, calling it "development debt":

When a profit unit has a goal to generate maximum profit for the shareholders, that kind of thinking leads to a situation where longer-term strategic development is carried out less than it should be, thus accumulating development debt in an organization. And if there is some man or a woman who sees retirement in a couple of years, then that is what you are tempted to do, collect all the money and leave the organization's development debt for others to pay.

\subsection{Misleading numbers}

The fourth disadvantage of accounting in the context of strategic thinking was connected to human interaction and organizational change. This theme of "misleading numbers" emphasized two perspectives. One, accounting information was found to be useful in promoting strategic change only to a limited extent. The strategy itself and the convincing story, including key supporting factors for it, were more relevant for decision-making and generating change. A director described the issue as one of presentation:

When you make long-term calculations you can say pretty much anything with them. In theatrical terms, it is a question of whether something is plausible or not, is it something that someone wants to hear or not. So in a way the other content of the strategy (other than accounting information) has to be so logical and convincing that you can think that these kinds of goals can be achieved.

Another interviewee summarized the problematics of promoting change in the following way:

Strategic issues are sold with a story. The story is more important than numbers.

Stories around strategic initiatives were described as something that inspired and directed the strategic thinking. Often these strategic stories, instead of accounting, were seen to be operating as guidelines to legitimate and to create frames for strategic thinking along the predefined strategic direction of the company.

The second aspect of misleading numbers involved a temptation to embellish them in favour of the strategic actions one is promoting. Respondents openly described a tendency to present numbers that favour a proposed initiative. One interviewee illustrates the point:

Typically you over-estimate the positive effects and underestimate the costs, that is very common. Probably it is typical for human beings to have overconfidence in the desired good outcomes. Often with strategic initiatives, the numbers are dressed up to be overly positive.

Another interviewee continued from the same perspective: 
Quite often the calculations around strategic issues have been made in a way that you can see the famous "hockey stick effect" in them. The historically proven performance has been a fairly steady growth and then the new suggested strategy is believed to take it to a completely new level. When we have analysed several strategic plans afterwards, we have found that those estimates and calculations that were originally presented had no connection to the actual outcomes. In my view, the phenomenon is about trying to justify that we are about to make a good choice.

Overall, the concerns regarding the use of accounting were widespread and as eminent in the data as the potential benefits of using accounting in the context of strategic thinking. Taken together, the results reported in this section suggest that the benefits and pitfalls form a tense, interesting role for accounting in managers' strategic thinking. The next chapter, therefore, moves on to discuss this observed duality of accounting and addresses its implications for accounting theory and research as well as management practice.

\section{Conclusion and discussion}

\subsection{Strategic thinking and accounting: elaborating a framework}

The results of this study described in the previous section can be further elaborated into a framework outlining the advantages and the disadvantages of using accounting in strategic contexts. Figure 1 presents the theorization of the results describing these potentials and pitfalls of accounting in strategic thinking on four distinct levels.

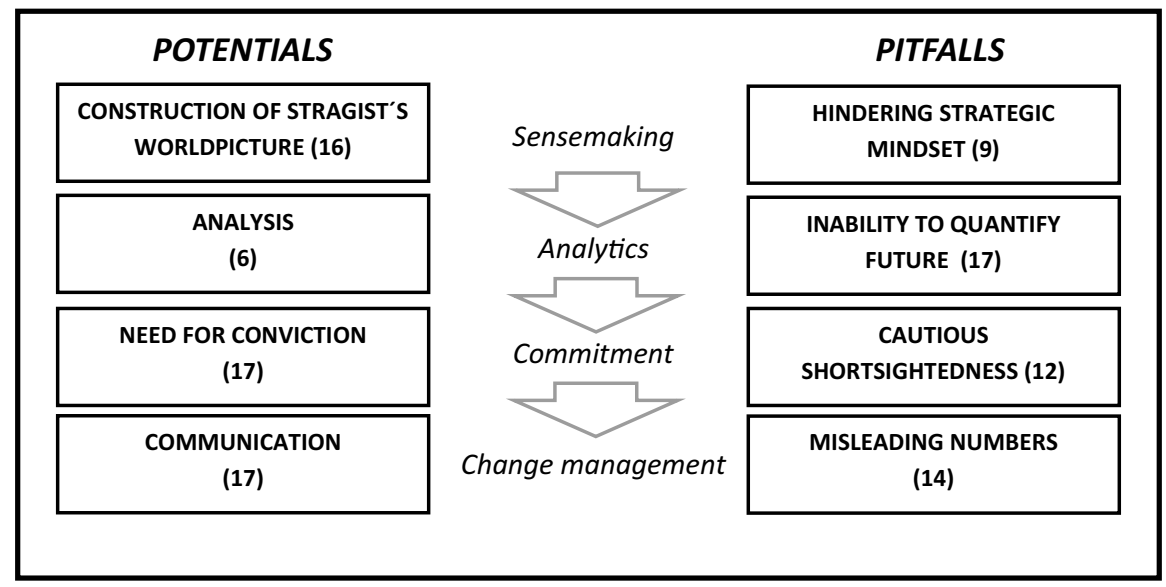

(Note: Numbers in brackets are frequency counts of the content analysis. They indicate how many of the 23 respondents described the theme)

Fig. 1 Potentials and pitfalls of accounting in strategic thinking 
Firstly, the results of this study emphasize the sensemaking perspective. Earlier work has explored the approaches used to make sense of strategic issues (Tillman and Goddard 2008; Haukedal and Gronhaug 1994) and found the strategic nature of management accounting information and its usability to depend upon the mindset adopted (Hutaibat et al. 2011). Furthermore, this process has been seen as leading to differing interpretations of the competitive arena (Hodgkinson and Johnson 1994). This research extends these observations even further. Whereas accounting can be seen to be useful in constructing a strategist's world-picture, it was also found that accounting can place limitations on the strategist's mindset and prevent different business opportunities from being seen. This shifts the focus from using accounting in decision-making into seeing its role in the construction of the strategist's mindset. The results of this study highlight the importance of managers' ongoing far-reaching efforts to make sense of what occurs and how various organizational accounting practices affect this, setting frames for their strategic thinking.

Secondly, though managers found accounting useful in assisting analytical thinking, they also often found its usefulness to be heavily limited and even admitted to sometimes abandoning it when outlining strategic initiatives. One of the most provocative findings in this study was that only a few respondents described the use of accounting for analytics to be especially valuable for them in strategic thinking. This can be partly explained by the research design, which deliberately concentrated on individual managers and one specific aspect of strategic management, the phase where ideas and initiatives are developed. A strategy execution perspective was addressed only in the sense of arguing for generated strategic initiatives in the organization, not in focusing on the actual implementation of the developed strategic initiatives. Previous research has suggested that, for example, innovation projects become more structured and formalized as they proceed from concept development to later phases (Chiesa et al. 2009). Nevertheless, the observed lack of use of explicit analytics and accounting information in strategic thinking is surprising considering how accounting is largely based on the idea of humans' external rationality. On the other hand, this study's finding that strategic initiatives cannot be easily evaluated and analysed beforehand suggests that accounting's role should be taken note of in other dimensions of strategic thinking.

Thirdly, accounting has a role in commitment, when managers devote themselves to the chosen strategic choices. This study suggests that managers do utilize accounting to test their assumptions and to satisfy their need for conviction. Nevertheless, it was noted that using accounting for gaining commitment can also lead to cautious short-sightedness. While it can be argued that this is what an accounting system is supposed to do (especially from a risk management perspective), this study suggests that what accounting professionals often regard as business partnering or financial developmental sparring of strategic initiatives can actually be, at times, discouraging from a strategist's perspective. These results also resonate with Lechner and Floyd (2011), who found that exploratory and innovative strategic initiatives are less likely to succeed in the resource allocation process. Interviewees saw the use of accounting as leading to feeling convinced and being committed to the strategic development in question, but sometimes also to the opposite result-over-cautiousness and short-sightedness. This offers a significant perspective especially on the stream of 
previous research that has pointed to the importance of management control systems in organizations' innovation activities (Davila et al. 2009; Simons 1995, 2000; Chenhall and Moers 2015).

Fourthly, accounting is also a vehicle for change management. Sometimes the use of accounting in this respect was related to official corporate policies and practices where strategic initiatives must be formalized and their financials made explicit. The interaction around strategic ideas was also emphasized, which resonated with the findings of previous research proposing that accounting systems should be used as communication platforms facilitating interaction and discussion regarding strategic decisions (Heidmann et al. 2008; Simons 1995; Jansen 2015; Chapman 1998; Chenhall 2003). Strategic initiatives require many people to be involved and managers also used accounting to influence the meaning construction of various organizational actors. These results corroborate the idea of Tavakoli and Lawton (2005), who state that the more an organization has people thinking strategically, the more readily it can respond to changes in the business environment. The power of accounting as a technology of distance (Robson 1992) when influencing other audiences should not be underestimated. Whereas accounting can be considered an appropriate vehicle for communicating strategic changes, it was described almost as often as being very limited and sometimes misused in that sense.

\subsection{Theoretical contribution}

In addition to outlining the previously described framework of the uses and disadvantages of accounting in strategic thinking, the findings from this study contribute to the current literature in three major respects. First, this article contributes to existing research on strategic thinking, which highlights explicit business impacts by suggesting that strategic thinking should be hypothesis driven (Liedtka 1998) and emphasizes a rational approach (Bonn 2005) and analytical thinking ability (Nuntamanop et al. 2013) as part of strategic thinking. Previous literature on strategic thinking (e.g. Zabriskie and Huellmantel 1991; Heracleous 1998; Liedtka 1998; Bonn 2001, 2005; Tavakoli and Lawton 2005; Nuntamanop et al. 2013) does not, however, outline any specific ways that accounting might play a role in strategic thinking of managers. This article contributes by providing the first comprehensive description of the forms accounting can take in these enacted, localized strategic thinking contexts. In addition to exploring the uses of accounting in strategic thinking, this article contributes to the literature problematizing the role of accounting in future-oriented strategic contexts (Choudhury 1988; Taipaleenmäki 2014; Cooper et al. 2001; Whittle and Mueller 2010; Sajasalo et al. 2016) by outlining reasons for why accounting is sometimes seen to be problematic and, therefore, absent in various cases.

Second, the findings from this study highlight a perspective that often goes unnoticed: that of individual managers. This research responds to calls for accounting research on the practitioners' perspective (e.g. Chua 2007; Jönsson 1998; Gerdin et al. 2014; Hall 2010; Lövstål and Jontoft 2017) and to study control and innovation on a more specific level than that of the organization (Davila et al. 2009; Tervala 
et al. 2017; Chenhall and Moers 2015; Davila et al. 2009), with a focus instead on subjective mechanisms and informal systems of control (Reimer et al. 2016; Tervala et al. 2017; Martyn et al. 2016). The results suggest that, from the perspective of an individual manager, strategic thinking is much more than straightforward analytical decision-making and the role of accounting is wide-ranging. The strategic decisions in managerial work that have to be made do not exist, as such, ready to be analytically solved. It is often the strategic thinker who outlines and constructs the strategic issue by interpreting the relevant information related to that issue and thereby constructing a worldview. Accounting can, in this setting, advance the strategic thinker's ability to outline which changes are essential. Whereas accounting was found to be useful in constructing the strategist's world-picture, it was also found to have another side. The results highlight that organizational accounting practices and financial goals set frames for the individual's strategic thinking. Financial constraints in strategic actions can limit the individual's freedom for interpretation and action. Organizational factors are also influential in the interpretation of strategic issues (Kuvaas and Kaufmann 2004). Kaikkonen (1994) emphasizes the independence of strategists, their responsibility for change and how the constructions of strategists' own world-picture must be left to the individual. Although this is a justifiable way of looking at the issue from a strategist's subjective perspective, this study revealed an emphasis on the organizational management control context. The need for strategic alignment (Akroyd et al. 2016; Slagmulder 1997) of the developed initiatives emphasized by the respondents reflected the goal congruence element of management control (Malmi and Brown 2008). When promoting the suggested strategic initiatives, managers often saw accounting as a benefit in communication regardless of whether they themselves had found accounting to be valuable during the previous phases of strategic development. In organizational managerial contexts, accounting information was used to reduce uncertainty (e.g. Frishammar 2003) and people favoured plausibility over accuracy (Weick 1995).

The third area where this study provides a theoretical contribution is in our understanding of the dual nature of accounting in strategic contexts. Whereas the existing research already provides interesting findings on the interplay of rationality and intuition in decision-making (e.g. Kahneman 2011; Calabretta et al. 2017; Langley 1995) and on the various positive and negative effects of accounting (e.g. Denis et al. 2006; Nutt 1998; Frishammar 2003; Kutschera and Ryan 2009; Cooper et al. 2001; Whittle and Mueller 2010; Mastilak et al. 2012), there have been few empirical investigations into expanding the view on accounting's dual-sided nature in strategic contents. Previous studies have recognized but not sufficiently addressed the duality of accounting in the context of strategic thinking. Although the previous work offers insight and frameworks for what accounts for the interplay and tension of this duality, the perspective remains a narrow one. This study suggests that the dual nature of accounting in strategic contexts is wider than the components of making a decision (analytics and commitment), extending to the initial framing of the strategic setting in the first place (sense making) and putting the choices made into action (change management).

The duality of accounting has become more important in light of recent approaches suggesting that management control and innovation can create tensions by presenting competing demands (Lövstål and Jontoft 2017) and that these tensions could be managed by paradoxical thinking, in which both approaches to the issue are 
leveraged (Calabretta et al. 2017). This study suggests that in addressing accounting in strategic thinking, we should shift the focus from a contingency approach (Chapman 1997; Chenhall 2003), which asks what management should emphasize what under what conditions, to seeing accounting and control as something that embraces opposing yet interrelated forces simultaneously. Whereas the contingency approach deals with tensions by seeking a balance that favours one competing demand at the expense of another, this study suggests that it is essential to manage competing demands simultaneously. The managers interviewed in this study highlighted both sides of the issue, emphasizing that resolving the tensions related to accounting and management control in strategic contexts does not mean eliminating them, but addressing competing demands simultaneously. These findings suggest that accounting and management control present themselves as competing demands. The findings are, furthermore, in line with Lövstål and Jontoft's (2017) view on competing demands and tensions at the intersection of management control and innovation. They also explain in more detail what Simons (1995) described as "belief system control", which guides and sets frames for strategic thinking and development.

One of the most significant findings to emerge from this study was how, from the managers' perspective, the advantages and disadvantages of using accounting presented themselves in a different way. The benefits of using accounting, such as in analytically outlining proposed strategic initiatives, were explicitly outlined and their potential benefits were anticipated in organizations. The disadvantages of accounting in strategic thinking, in turn, presented themselves latently and, even surprisingly, as pitfalls during the process. These included the use accounting as leading to cautious shortsightedness, which was seen to emerge imperceptibly over the course of time. Whereas management control and accounting systems can be intentionally designed by top management to constrain as well as to enable strategic exploration, it was more often the benefits of using accounting that were expected to influence the strategic thinking process. Existing research has outlined a variety of disadvantages of accounting in strategic contexts, but the findings of this study show that, for managers, they appear in a different way than the anticipated benefits do. These results may be explained through the nature of strategic thinking, which involves learning and interaction and developing the outcome in a creative process. That creates a context where the use of predefined management control systems and accounting practices might lead to the emergence of various disadvantages.

This study suggests that the duality of accounting in strategic thinking can be approached as a paradox, stemming from cognitively and/or socially constructed polarities (Lewis 2000). For example, whereas rational use of analysis and accounting information can be an appropriate approach to avoid the flaws of fast intuitive human thinking (Langley 1995; Kahneman 2011), this study suggests that slower analytical thinking comes with its own disadvantages when applied in strategic contexts. Whereas the use of accounting creates understanding, clarity and commitment, it paradoxically can simultaneously narrow the strategic mindset and create cautious shortsightedness. These findings suggest that accounting in managers' strategic thinking is represented as a range of benefits and pitfalls, as a paradoxical duality that cannot be fully solved but the tensions of which must be confronted. This 
paradoxical approach assumes that any exclusive choice among opposing forces in managerial work is temporary and the tension will resurface.

\subsection{Managerial implications}

This study offers a number of implications for managerial work. In strategic thinking, being aware of your own perceptions is essential. Approaching accounting in strategic thinking as a paradox, as representing contradictory yet interrelated elements, offers a new perspective for management. Instead of seeing organizational tensions as a dilemma of competing choices (e.g. the freedom to innovate vs. the need for control and alignment), they should be accepted as a paradoxical duality. By applying paradoxical thinking managers can make latent opposing forces more explicit, thus creating a more powerful context for creative strategic thinking. Seeing accounting's role in strategic thinking with its all tensions and dimensions is especially important in this age, which fosters the continuous pursuit of opportunities for significant new value creation. For example, unintended consequences of accounting and management control leading to cautious short-sightedness might be especially harmful in an everchanging business environment and with an increasing demand to emphasize continuous learning and agile experimentation. This study highlights the importance of managers seeing the entire range of benefits and pitfalls of accounting in strategic thinking. It would be remarkable to suppose that when management thinking becomes strategic, considering issues in terms of money and management control would be irrelevant and hence accounting would have no role. Leading an innovative organization is paradoxical and tensions stemming from its processes should be carefully managed (Pisano 2019). The framework outlined in this study can be used to inform strategic development activities in companies by utilizing an accounting perspective in the process.

\subsection{Limitations and suggestions for further research}

This research does have limitations. QCA as a method helps describe material only in those respects specified by the researcher. The method does not allow describing the full meaning of the material in each and every respect. In this study, a choice was made to examine the use and lack of use of accounting in managers' strategic thinking. This article does not offer a definite conclusion on whether managers find accounting to be useful or not overall. Rather, it offers a holistic collection of experienced potentials and pitfalls of the use of accounting in a strategic context. The formed concepts can also be interrelated, a disadvantage for one company could be an advantage to another company. This is very much dependent on the strategy being pursued. This study did not aim to cover all aspects related to strategic issues and accounting in companies. The aim was instead to investigate and study individual managers' interpretations of the situation. Such a focus excludes many significant questions related to, for example, organizational practices and general prevalence regarding management control systems, management accounting and strategy processes. Notwithstanding these limitations, this article makes a potentially important 
contribution towards the understanding of accounting in strategic thinking. The findings of this study are relevant to researchers looking to study accounting from the perspective of one of its most important users, managers. Studying the strategic thinking of practicing managers from an accounting perspective helps researchers move beyond the numbers to see the strategic thinking of managers as a world that is far richer and more complex than is often assumed. The focus of this research has been on building an initial theoretical framework. Future research could expand the understanding of accounting and strategic thinking by further developing and applying this study's findings with more details. Further work is needed to fully understand the situated nature of accounting and to assess more specifically those contexts in which managers value its usefulness and those in which they are wary of its disadvantages. More broadly, this study has highlighted that understanding of accounting from the perspective of practicing managers is still in need of further research. It also invites managers and accounting professionals to make connections between the outlined elements of accounting in strategic thinking and their own experience.

Acknowledgement Open access funding provided by University of Jyväskylä (JYU).

Funding This research was partly supported by Finnish Foundation for Economic Education (Grant No. 01/2014), and Jenny and Antti Wihuri Foundation (Grant No. 2014).

Open Access This article is distributed under the terms of the Creative Commons Attribution 4.0 International License (http://creativecommons.org/licenses/by/4.0/), which permits unrestricted use, distribution, and reproduction in any medium, provided you give appropriate credit to the original author(s) and the source, provide a link to the Creative Commons license, and indicate if changes were made.

\section{Appendix A}

EMBA final theses topics on strategic thinking

1. Local food as a competitive advantage for company $\mathrm{X}$

2. Renewed business and contracting model securing the future of company $X$

3. Strategic knowledge-base of managing a municipal enterprise group

4. Account management in a small design-company- "Most wanted partner in visual communications"

5. Research on the success factors of a new product in bank Group X

6. Differentiating solutions value on customer relationship with the help of customer insight

7. Overwhelming customer experience-Concept manual for the business of the future in company $\mathrm{X}$

8. Developing marketing and services to Russian customers in company $\mathrm{X}$

9. Building an education value network in industry $X$

10. Pricing as a competitive advantage in retail. Effect of impression about the price in choosing where to buy

11. With innovations to a sustainable tomorrow-Innovation process as part of sustainable business

12. Life Cycle planning and roadmaps for existing customers in company $\mathrm{X}$

13. ICT-governance and organizational architecture in organization $X$

14. The triple helix institute of higher education on entrepreneurship — continuous renewal and management challenges 
15. From cooperation to partnership-development of suppliers relationships in company X

16. Strategy work of multi-actor organization-case organization $\mathrm{X}$

17. Customer service improvement in business area $\mathrm{X}$

18. Learning story about building an innovation system into enterprise $\mathrm{X}$

19. Perspectives into the future of field of industry $X$

20. Account management in municipalities

21. Customer as a developer of products and services

22. Success factors of the future in the field of industry $X$

23. Hurricane-Business of a company $\mathrm{X}$

24. Competitive strategy of goods trade in Company X and send-offs for successful strategy implementation

25. Local supplier of the future in company $X$

26. Growth strategy of sales in company X

\section{Appendix B}

Interview questions - areas of enquiry

Current work

Describe your work and area of managerial responsibility

How do you know you have done a good job?

How are accounting and financial issues related to your work?

What accounting practices you find useful/not useful in your work?

Strategic thinking

How do you plan ahead and practice strategic foresight in your work?

How can one know if some new idea or a plan might turn out to be strategically significant?

When was the last time you practiced strategic thinking?

How do you define goals for strategic development?

What is your personal view on strategic development of your business based on?

How are strategic ideas and initiatives sold and operationalized in an organization?

Do you see any dangers and challenges related to strategic thinking?

Strategy and accounting issues

What is the role of financial information in strategic thinking?

When creating and envisioning something new, what accounting frameworks and practices you consider useful/not useful?

Do you produce calculations yourself in your work? Do you utilize calculations made by others?

Do you see any challenges or dangers when using accounting in strategy work?

Is there something else you would like to tell about strategic thinking and accounting related to your work and experience?

Strategic thinking case: EMBA final thesis project

How would you describe your EMBA final thesis as a project (time span, who was involved etc.)?

How would you evaluate it now as a strategic project?

How would you estimate the financial impact of the project?

How would you describe accounting thinking and financial quantifications as part of the project? 


\section{Appendix C}

Descriptive details of interviewees

\begin{tabular}{|c|c|c|c|c|c|c|}
\hline & \multirow[t]{2}{*}{ Job title } & \multicolumn{2}{|c|}{ Company size ${ }^{a}$} & \multirow[t]{2}{*}{ Field of industry } & \multirow[t]{2}{*}{ Age } & \multirow[t]{2}{*}{ Gender } \\
\hline & & SME & Large & & & \\
\hline 1 & Production director & & $\mathrm{x}$ & Manufacturing & 45 & M \\
\hline 2 & Business director & & $\mathrm{X}$ & Education services & 46 & M \\
\hline 3 & Account director & $\mathrm{X}$ & & Professional services & 49 & $\mathrm{~F}$ \\
\hline 4 & Senior project manager & $\mathrm{x}$ & & Education services & 46 & M \\
\hline 5 & Manager of product management & $\mathrm{x}$ & & Technical wholesale & 41 & M \\
\hline 6 & $\mathrm{CIO}$ & & $\mathrm{x}$ & ICT services & 43 & M \\
\hline 7 & Development director & & $\mathrm{X}$ & Media & 54 & M \\
\hline 8 & Finance manager & & $\mathrm{x}$ & Energy & 47 & M \\
\hline 9 & Production unit director & $\mathrm{X}$ & & Food industry & 55 & M \\
\hline 10 & Executive director & $\mathrm{x}$ & & Professional services & 50 & $\mathrm{~F}$ \\
\hline 11 & Director & $\mathrm{x}$ & & Social services & 54 & $\mathrm{~F}$ \\
\hline 12 & Director & & $\mathrm{x}$ & Public sector & 35 & M \\
\hline 13 & Sales manager & & $\mathrm{x}$ & Food Industry & 44 & $\mathrm{~F}$ \\
\hline 14 & Director of administration & & $\mathrm{X}$ & Public sector & 53 & $\mathrm{~F}$ \\
\hline 15 & Category manager & & $\mathrm{x}$ & Retail & 45 & M \\
\hline 16 & Account director & & $\mathrm{x}$ & Real estate services & 49 & M \\
\hline 17 & $\mathrm{CEO}$ & $\mathrm{x}$ & & Travel & 48 & $\mathrm{~F}$ \\
\hline 18 & Development director & & $\mathrm{x}$ & Finance & 57 & $\mathrm{~F}$ \\
\hline 19 & Director & & $\mathrm{X}$ & Energy & 46 & $\mathrm{~F}$ \\
\hline 20 & Director & & $\mathrm{x}$ & Software & 46 & M \\
\hline 21 & $\mathrm{CIO}$ & & $\mathrm{x}$ & Healthcare & 49 & M \\
\hline 22 & Channel development manager & & $\mathrm{x}$ & Food industry & 56 & M \\
\hline 23 & Administration manager & $\mathrm{X}$ & & Real estate services & 39 & $\mathrm{~F}$ \\
\hline
\end{tabular}

${ }^{a}$ Small and medium-size enterprise (SME) definition according to European Union recommendation 2003/361, meaning organisations with less than 250 employees

\section{References}

Abraham, S. (2005). Stretching strategic thinking. Strategy and Leadership, 33(5), 5-12.

Adler, P. S. (2012). The sociological ambivalence of bureaucracy: From Weber via Gouldner to Marx. Organization Science, 23, 244-266.

Adler, P. S., \& Borys, B. (1996). Two types of bureaucracy: Enabling and coercive. Administrative Science Quarterly, 41, 61-89.

Ahrens, T., \& Chapman, C. S. (2004). Accounting for flexibility and efficiency: A field study of management control systems in a restaurant chain. Contemporary Accounting Research, 21, 271-301.

Akroyd, C., Biswas, S. S. N., \& Chuang, S. (2016). How management control practices enable strategic alignment during the product development process. In M. J. Epstein \& M. A. Malina (Eds.), Advances in management accounting (Vol. 26, pp. 99-138). Bingley: Emerald Group Publishing Limited. 
Anthony, R. N. (1965). Planning and control systems: A framework for analysis. Cambridge: Division of Research, Graduate School of Business Administration, Harvard University.

Benito-Ostolaza, J. M., \& Sanchis-Llopis, J. A. (2014). Training strategic thinking: Experimental evidence. Journal of Business Research, 67, 785-789.

Bisbe, J., \& Malagueno, R. (2009). The choice of interactive control systems under different innovation management modes. European Accounting Review, 18, 371-405.

Bisbe, J., \& Otley, D. (2004). The effects of interactive use of management control systems on product innovation. Accounting, Organizations and Society, 29, 709-737.

Bonn, I. (2001). Developing strategic thinking as a core competency. Management Decision, 39, 63-71.

Bonn, I. (2005). Improving strategic thinking: A multilevel approach. Leadership \& Organization Development Journal, 26, 336-354.

Brandau, M., \& Hoffjan, A. H. (2010). Exploring the involvement of management accounting in strategic decisions and control: The case of offshoring. Journal of Accounting \& Organizational Change, 6 , 72-95.

Brouthers, K. D., \& Roozen, F. A. (1999). Is it time to start thinking about strategic accounting? Long Range Planning, 32, 311-322.

Burkert, M., Fischer, F. M., \& Schäffer, U. (2011). Application of the controllability principle and managerial performance: The role of perceptions. Management Accounting Research, 22, 143-159.

Busch, T. (1997). Management, accounting and cognition. Scandinavian Journal of Management, 13, $39-49$.

Calabretta, G., Gemser, G., \& Wijnberg, N. M. (2017). The interplay between intuition and rationality in strategic decision making: A paradox perspective. Organization Studies, 38, 365-401.

Casey, A. J., \& Goldman, E. F. (2010). Enhancing the ability to think strategically: A learning model. Management Learning, 41, 167-185.

Chapman, C. S. (1997). Reflections on a contingent view of accounting. Accounting, Organizations and Society, 22, 189-205.

Chapman, C. S. (1998). Accountants in organizational networks. Accounting, Organizations and Society, 23, 737-766.

Chenhall, R. H. (2003). Management control systems design within its organizational context: Findings from contingency-based research and directions for the future. Accounting, Organizations and Society, 28, 127-168.

Chenhall, R. H., \& Moers, F. (2015). The role of innovation in the evolution of management accounting and its integration into management control. Accounting, Organizations and Society, 47, 1-72.

Chiesa, V., Federico, F., Lucio, L., \& Giuliano, N. (2009). Exploring management control in radical innovation projects. European Journal of Innovation Management, 12, 416-443.

Choudhury, N. (1988). The seeking of accounting where it is not: Towards a theory of non-accounting in organizational settings. Accounting, Organizations and Society, 13, 549-557.

Chua, W. F. (2007). Accounting, measuring, reporting and strategizing-Re-using verbs: A review essay. Accounting, Organizations and Society, 32, 487-494.

Cinquini, L., \& Tenucci, A. (2010). Strategic management accounting and business strategy: A loose coupling? Journal of Accounting \& Organizational Change, 6, 228-259.

Cooper, S., Crowther, T., \& Carter, C. (2001). Challenging the predictive ability of accounting techniques in modelling organizational futures. Management Decision, 39, 137-146.

Davila, T. (2000). An empirical study on the drivers of management control systems' design in new product development. Accounting, Organizations and Society, 25, 383-409.

Davila, A., Foster, G., \& Oyon, D. (2009). Accounting and control, entrepreneurship and innovation: Venturing into new research opportunities. European Accounting Review, 18, 281-311.

Denis, J.-L., Langley, A., \& Rouleau, L. (2006). The power of numbers in strategizing. Strategic Organization, 4, 349-377.

Ditillo, A. (2012). Designing management control systems to foster knowledge transfer in knowledgeintensive firms: A network-based approach. European Accounting Review, 21, 425-450.

Dragoni, L., Oh, I., Vankatwyk, P., \& Tesluk, P.-E. (2011). Developing executive leaders: The relative contribution of cognitive ability, personality, and the accumulation of work experience in predicting strategic thinking competency. Personnel Psychology, 65, 829-864.

Duhamel, F., Reboud, S., \& Santi, M. (2014). Capturing value from innovations: The importance of rent configurations. Management Decision, 52, 122-143. 
Duriau, V. J., Reger, R. K., \& Pfarrer, M. D. (2007). A content analysis of the content analysis literature in organisational studies: Research themes, data sources, and methodological refinements. Organizational Research Methods, 10, 5-34.

Dutton, J. E., Ashford, S. J., O’Neill, R. M., \& Lawrence, K. A. (2001). Moves that matter: Issue selling and organizational change. Academy of Management Journal, 33, 716-736.

Feeney, O., \& Pierce, B. (2016). Strong structuration theory and accounting information: An empirical study. Accounting, Auditing \& Accountability Journal, 29, 1152-1176.

Frishammar, J. (2003). Information use in strategic decision making. Management Decision, 41, 318-326.

Gerdin, J., Messner, M., \& Mouritsen, J. (2014). On the significance of accounting for managerial work. Scandinavian Journal of Management, 30, 389-394.

Goldman, E. F. (2005). Becoming an expert strategic thinker: The learning journey of healthcare CEOs. UMI dissertations publishing, George Washington University.

Goldman, E. F. (2012). Leadership practices that encourage strategic thinking. Journal of Strategy and Management, 5, 25-40.

Goretzki, L. (2013). Management accounting and the construction of the legitimate manager. Journal of Management Control, 23, 319-344.

Graetz, F. (2002). Strategic thinking versus strategic planning: towards understanding the complementaries. Management Decision, 40, 456-462.

Hall, M. (2010). Accounting information and managerial work. Accounting, Organisations and Society, $35,301-315$.

Haukedal, W., \& Gronhaug, K. (1994). Context-specific rationality in sense-making of strategic stimuli. Scandinavian Journal of Management, 10, 355-367.

Heidmann, M., Schäffer, U., \& Strahringer, S. (2008). Exploring the role of management accounting systems in strategic sensemaking. Information Systems Management, 25, 244-257.

Heracleous, L. (1998). Strategic thinking or strategic planning. Long Range Planning, 31, 481-487.

Hodgkinson, G. P., \& Johnson, G. (1994). Exploring the mental processes of competitive strategists: The case for a processual approach. Journal of Management Studies, 31, 525-551.

Hsieh, H. F., \& Shannon, S. E. (2005). Three approaches to qualitative content analysis. Qualitative Health Research, 15, 1277-1288.

Hutaibat, K., Alberti-Alhtaybat, L., \& Al-Htaybat, K. (2011). Strategic management accounting and the strategising mindset in an English higher education institutional context. Journal of Accounting \& Organizational Change, 7, 358-390.

Jansen, P. E. (2015). Participation, accounting and learning how to implement a new vision. Management Accounting Research, 29, 45-60.

Jönsson, J. (1998). Relate management accounting research to managerial work! Accounting, Organisations and Society, 23, 411-434.

Jordan, S., \& Messner, M. (2012). Enabling control and problem of incomplete performance indicators. Accounting, Organizations and Society, 37, 544-564.

Jorgensen, B., \& Messner, M. (2010). Accounting and strategizing: A case study from new product development. Accounting, Organizations and Society, 25, 184-204.

Kahneman, D. (2011). Thinking, fast and slow. New York: Allan Lane.

Kaikkonen, V. (1994). Ihminen, strategia-ajattelu ja laskentatoimi (Vol. 420)., Acta Universitatis Tamperesis ser A Tampere: University of Tampere.

Kaplan, R. S., \& Norton, D. P. (1996). The balanced scorecard: Translating strategy into action. Boston: Harvard Business Press.

Kaplan, R. S., \& Norton, D. P. (2004). Strategy maps: Converting intangible assets into tangible outcomes. Boston: Harvard Business Press.

Kast, F. E., \& Rosenzweig, J. E. (1970). Organization and management: A systems approach. New York: McGraw-Hill.

Kaufman, R., Oakley-Brown, H., Watkins, R., \& Leigh, D. (2003). Strategic planning for success: Aligning people, performance and payoffs. San Francisco: Pfeiffer.

Kutschera, I., \& Ryan, M. (2009). Implications of intuition for strategic thinking: practical recommendations for gut thinkers. S.A.M. Advanced Management Journal, 74, 12-20.

Kuvaas, B., \& Kaufmann, G. (2004). Individual and organizational antecedents to strategic-issue interpretation. Scandinavian Journal of Management, 20, 245-275.

Laamanen, T. (2017). Reflecting on the past 50 years of Long Range Planning and a research agenda for the next 50. Long Range Planning, 50, 1-7. 
Langfield-Smith, K. (2008). Strategic management accounting: How far have we come in 25 years? Accounting, Auditing \& Accountability Journal, 21, 204-228.

Langley, A. (1989). In search of rationality: The purposes behind the use of formal analysis in organizations. Administrative Science Quarterly, 34, 598-631.

Langley, A. (1995). Between "Paralysis by Analysis" and "Extinction by Instinct". Sloan Management Review, 36, 63-76.

Lechner, C., \& Floyd, S. W. (2011). Group influence activities and the performance of strategic activities. Strategic Management Journal, 33, 478-495.

Lewis, M. W. (2000). Exploring paradox: Toward a more comprehensive guide. Academy of Management Review, 4, 760-776.

Liedtka, J. M. (1998). Strategic thinking: Can it be taught? Long Range Planning, 31, 120-129.

Lövstål, E., \& Jontoft, A. (2017). Tensions at the intersection of management control and innovation: A literature review. Journal of Management Control, 28, 41-79.

Malmi, T., \& Brown, D. A. (2008). Management control systems as a package-Opportunities, challenges and research directions. Management Accounting Research, 19, 287-300.

Martyn, P., Sweeney, B., \& Curtis, E. (2016). Strategy and control: 25 years of empirical use of simons' levers of control framework. Journal of Accounting \& Organizational Change, 12, 281-324.

Mastilak, C., Matuszewski, L., Miller, F., \& Woods, A. (2012). Evaluating conflicting performance on driver and outcome measures: the effect of strategy maps. Journal of Management Control, 23, 97-114.

Miller, P., \& Power, M. (2013). Accounting, organizing, and economizing: Connecting accounting research and organization theory. The Academy of Management Annals, 7, 557-605.

Mintzberg, H. (1994). The rise and fall of strategic planning. New York: Prentice-Hall.

Moon, B. (2013). Antecedents and outcomes of strategic thinking. Journal of Business Research, 66, 1698-1708.

Mouritsen, J., Hansen, A., \& Hansen, C. O. (2009). Short and long translations: Management accounting calculations and innovation management. Accounting, Organizations and Society, 34, 738-754.

Mueller, C., Mone, M. A., \& Barker, V. L., III. (2007). Formal strategic analyses and organizational performance: Decomposing the rational model. Organization Studies, 28, 853-883.

Näsi, J. (1991). Strategic thinking as doctrine, development of focus areas and new insight. In J. Näsi (Ed.), Arenas of strategic thinking. Foundation of Economic Education: Helsinki.

Nixon, B. (1998). Research and development performance measurement: A case study. Management Accounting Research, 9, 329-355.

Nixon, B., \& Burns, J. (2012). The paradox of strategic management accounting. Management Accounting Research, 23, 229-244.

Nordqvist, M., \& Melin, L. (2008). Strategic planning champions: Social craftpersons, artful interpreters and known strangers. Long Range Planning, 41, 326-344.

Nuntamanop, P., Kauranen, I., \& Igel, B. (2013). A new model of strategic thinking competency. Journal of Strategy and Management, 6, 242-264.

Nutt, P. C. (1998). How decision makers evaluate alternatives and the influence of complexity. Management Science, 44, 1148-1166.

Nyamori, R. O., Perera, M. H. P., \& Lawrence, S. R. (2001). The concept of strategic change for management accounting research. Journal of Accounting Literature, 20, 62-83.

Otley, D. (1994). Management control in contemporary organizations: Towards a wider framework. Management Accounting Research, 5, 289-299.

Pärl, Ü. (2014). The role of dialogue between executives and ground-level employees mediated by MACS. Baltic Journal of Management, 9, 189-212.

Patton, M. Q. (2002). Qualitative research and evaluation methods (3rd ed.). Thousand Oaks, CA: Sage.

Pfister, J. A., Jack, S., \& Darwin, S. N. (2017). Strategizing open innovation: How middle managers work with performance indicators. Scandinavian Journal of Management, 33, 139-150.

Pisano, G. (2019). The hard truth about innovative cultures. Harvard Business Review, 97, 62-71.

Porter, T. M. (1995). Trust in numbers: The pursuit of objectivity in science and public life. Princeton, NJ: Princeton University Press.

Puhakka, H. (2017). The role of accounting in making sense of post-acquisition integration. Scandinavian Journal of Management, 33, 12-22.

Reimer, M., Van Doorn, S., \& Heyden, M. L. M. (2016). Managers and the management control systems in the strategy process. Journal of Management Control, 27, 121-127.

Revellino, S., \& Mouritsen, J. (2015). Accounting as an engine: The performativity of calculative practices and the dynamics of innovation. Management Accounting Research, 28, 31-49. 
Robson, K. (1992). Accounting numbers as "inscription": Action at a distance and the development of accounting. Accounting, Organizations and Society, 17, 685-708.

Roslender, R., \& Hart, S. J. (2003). In search of strategic management accounting. Management Accounting Research, 14, 255-279.

Sajasalo, P., Auvinen, T., Takala, T., Järvenpää, M., \& Sintonen, T. (2016). Strategy implementation as fantasising-Becoming the leading bank. Accounting and Business Research, 46, 303-325.

Schreier, M. (2012). Qualitative content analysis in practice. Thousand Oaks: Sage Publications Limited.

Schreier, M. (2014). Qualitative content analysis. In U. Flick (Ed.), The SAGE handbook of qualitative data analysis. London: Sage Publications Ltd.

Simons, R. (1995). Levers of control: How managers use innovative control systems to drive strategic renewal. Boston, MA: Harvard Business School Press.

Simons, R. (2000). Performance measurement and control systems for implementing strategy: Text and cases. Upper Saddle River, NJ: Prentice Hall.

Slagmulder, R. (1997). Using management control systems to achieve alignment between strategic investment decisions and strategy. Management Accounting Research, 8, 103-139.

Sloan, J. (2014). Learning to think strategically. Oxford: Elsevier.

Smith, W. K., \& Lewis, M. W. (2011). Toward a theory of paradox: A dynamic equilibrium model of organizing. Academy of Management Review, 36, 381-403.

Stacey, R. (1992). Managing the unknowable: strategic boundaries between order and chaos in organizations. San Francisco: Jossey-Bass Wiley Company.

Steptoe-Warren, G., Howat, D., \& Hume, I. (2011). Strategic thinking and decision making: Literature review. Journal of Strategy and Management, 4, 238-250.

Strauß, E., \& Zecher, C. (2013). Management control systems: A review. Journal of Management Control, 23, 233-268.

Taipaleenmäki, J. (2014). Absence and variant modes of presence of management accounting in new product development-Theoretical refinement and some empirical evidence. European Accounting Review, 23, 291-334.

Tavakoli, I., \& Lawton, J. (2005). Strategic thinking and knowledge management. Handbook of Business Strategy, 6, 155-160.

Tayles, M., Pike, R., \& Sofian, S. (2007). Intellectual capital, management accounting practices and corporate performance. Accounting, Auditing and Accountability Journal, 20, 522-548.

Tervala, E., Laine, T., Korhonen, T., \& Suomala, P. (2017). The role of financial control in new product development: empirical insights into project managers' experiences. Journal of Management Control, 28, 81-106.

Tillman, K., \& Goddard, A. (2008). Strategic management accounting and sense-making in a multinational company. Management Accounting Research, 19, 80-102.

Weber, R. (1990). Basic content analysis. Thousand Oaks, CA: Sage Publications.

Weick, K. E. (1995). Sensemaking in organizations. Thousand Oaks, CA: Sage Publications.

Whittle, A., \& Mueller, F. (2010). Strategy, enrollment and accounting: the politics of strategic ideas. Accounting, Auditing and Accountability Journal, 23, 626-646.

Zabriskie, N. B., \& Huellmantel, A. B. (1991). Developing strategic thinking in senior management. Long Range Planning, 24, 25-32.

Publisher's Note Springer Nature remains neutral with regard to jurisdictional claims in published maps and institutional affiliations. 